\title{
UEFA CRITERIA AND CLUB MANAGEMENT
}

\section{Serdar SAMUR}

\begin{abstract}
After the 1990's, the changes in the football world had helped to develop and to grow the economy of football rapidly. The development of digital broadcasting led to build a bigger commercial structure. With the effect of those changes, commercial incomes, sponsor revenues, stadium and facilities incomes, and betting incomes have increased over time. This rapid change also brings several problems.

UEFA has published UEFA criteria in order to protect football's sustainability and viability in a long term. Depending on license criteria that is published by UEFA, it has used a road map for football clubs, regarding of corporate structure of UEFA to work, that identified the general rules like in a company structure and management that should be all the necessary factors of production in a systematic and effective way in order to transform football clubs to a corporate organization and make them sustainable.

Football clubs are determinedly founded and play an important role in the improvement of football player. However, few resources are available for those responsible for organizing, developing, and managing club sports.

With this out of the common guide explains readers how to run a club in today's demanding, high competitive and high-tech environment and, establish its brand, and bring in the revenue required to ensure long-term success. Those who manage and lead clubs will find that they can improve a successful business plan of their club mission and have the instruments to develop and sustain organizations that are feasible and financially wealthy and that satisfy the needs of footballer and those who support them.
\end{abstract}

Key words: UEFA Criteria, Sports Management, Football, Success, Football Player

\section{Introduction}

As a global phenomenon, sport is spreading depending on the socio-economic conditions of societies, on the other hand, it is also beginning to show itself economically as much as in sport industry.

Some issues in sports due to paying astronomical transfer fees to athletes, appearing world clubs in global stage, following sport organizations by millions of people, advertising and sponsorship agreements, and a contribution to the country presentation help to become sport industry more important such as organization and facility investments, sport accommodations, sports fans, the broadcasting of sport organizations, food-drink industry, sport souvenirs, sports clothing, and so on. People and organizations in this industry have changed over time; clubs were converted into a business, fans and spectators were converted into a consumer. Since the beginning of the 1990's, the sport industry has seen as a profitable area and incorporation of the professional sport organizations or teams, public offering, higher ticket prices and broadcasting rights changed the Figure of the sport industry. Football is the biggest part of sport economics that has rapidly moved away from Olympics understanding and become one of commercial branch like a tradable meta. The organizational structure of football teams, the size of incomes, the features of fans, the physical conditions of stadiums, physical and technical capacities of the players, the tactical and technical skills of coaches, written and visual media of the sport which are running to manage the dynamics of sport has been changed. The football which is the driving force of sport and being the most important part of sport industry. The football teams in the past were managed with an amateur understanding and continuously resulted in the failures. Therefore, today they need to restructure in terms of financial, legal, social, and organizational aspects.

\section{Aim and objective of the study}

uEFA criteria are determined by UEFA that these are mandatory to be applied for all professional sports club as the target audience that will be participated in the Europe Cups. UEFA criteria has been declared by UEFA as mandatory criteria since 2014. There are financial and sporting sanctions in case of failure to comply with these criteria.

Although Criteria attributed so much importance they are not known exactly what kind of contributions to sports club management and sporting success. 
The Primary goal of this research is conducted to identify How can be defined the effects of UEFA criteria on managing of the professional Football Clubs effectively and efficiently to provide the sporting success.

\section{Methodology of the research}

the model I present here has three components, each of which addresses a specific set of concerns: this research will be examined in accordance with qualitative research methods.

In qualitative research method, the Descriptive Approach and Phenomenological Qualitative research designs were used for the model of this research.

\section{Discussion}

Sport Management:

In sports, as in other businesses, managers determine organizational performance both on and off the playing field. Sport management programs train people for management positions in such areas as college athletics, professional teams, fitness centers, recreational centers, coaching, officiating, marketing, youth organizations, and sporting goods manufacturing and retailing. (Lussier \& Kimball, 2004)

Sport management means, management of all activities that is required to fulfill all tasks within a business or organization as a performance process. (Steinmann and Schreyögg, 1997).

Human Resources Management:

Every team and organization is only as good as its players and workers. Thus, the key driver of business success is human resource (HR) management practices of hiring and developing great people. Human Resources management consist of planning, attracting, developing, and retaining employees. HR practice affect firm performance, and even more important in high-growth firms. (Karl, 2006)

Organization Management:

When applying the basic principles of corporate governance, planning an organization according to the organizational goals, converting these plans into actions, and tracking the reached point that will start on a systematic process of TQM within our sport system. Competitive power of the organization in service area will be evaluated on Organizational Learning, Brand and Corporate Communications, Financial Management, Organizational
Culture and Strategic Management. (Uluslararas1 Spor Araştırmaları Dergisi, 2010)

An effective organization management needs someone who has management skills which compromise; technical skills, people skills, communication skills, conceptual skills, and decision- making skills. (Katz.,1974)

Organizational Learning:

Today's managers are knowledge workers, which is a change in the realm of management. (Gupta, 2005). Knowledge is a dominant source of competitive advantage (Jansen et all, 2006), because knowledge leads to creativity and innovation action. Success often comes from recognizing new opportunities through knowledge of a market, industry, or customers. (Baron, 2006). The learning organization is based on knowledge. In a learning organization, everyone understands that the world is changing rapidly and, that they must not only be aware of these changes but also adapt to the changes and, more important, be forces for change. The learning organization has a capacity to learn, adapt, and change as its environment changes to continuously increase customer value.

Brand Value and Corporate Communications:

When a sport organization is able to achieve a strong image in the consumer's mind, it realizes brand equity. According to David Aaker, a leading expert on branding, brand equity is " a set of assets and liabilities linked to a brand, its name and symbol, that add to or subtract from the value provided by a product or service to a firm and/or that firm's customers" when a team such as Manchester United is able to generate a wealth of assets linked to its brand, the team is thought to have high brand equity. This is the ultimate goal for the sport franchise manager because there are a number of benefits to having high levels of brand equity. (Trecker, 2004)

Strategic Thinking:

The strategic management process is generally though to consist of five sequential and continuing steps (Takagawa, 1995)

- Environmental analysis

- Establishment of an organizational direction,

- Strategy formulation,

- Strategy implementation,

- Strategic Control. 
Sport Facilities Management:

The value of sport in each case depends on the ways that sport is managed, and without facilities there is no sport. There are many sport management jobs related to facilities management, including facility financing, construction, facility operations, user agreements, and insurance (MacMillen, 2007), and the job of sport-facility security has increased in importance since September 11, 2001 (Appelbaum et. all, 2005). Sport management professionals often find careers in managing various type of facilities. Such these work includes managing provide health clubs, fitness centers, managing anything from indoor sporting centers to entire stadiums. Facility managers are challenged daily basis while the facility management industry continues to grow. Club managers are involved with scheduling events, arranging for transportation, managing event security, and food concessions are ready before the game time.

\section{Sports Marketing:}

Sport marketing consists of all activities designed to meet the needs and wants of sport consumers through exchange process. Sport marketing has developed two major thrusts: the marketing of sport products and services directly to consumers of sport, and the marketing of other consumer and industrial products or services through the use of sport promotions. (Mullin et. all, 2007)

The sport product is both an integrated ensemble and a bunch of components with lives of their own. At the core is the "Event Experience, composed of four components" (Mullin et. all, 2007)

Game Form, Player, Equipment and Apparel, Venue. Everything else builds on these components.

The products produced by the clubs has been expanding three areas: fan products, rights and services.

Sponsorship:

Often a company will negotiate a sponsorship or licensing agreement that designates that company as the exclusive sponsor. The benefit of this type of sponsorship is a high level of exposure without the competition and clutter of traditional advertising. In other words, sponsorship can serve as a subtler alternative to advertising; sponsorship may communicate the company's message in a different, "new" and "less commercial" form. (Littman, 1997)
Sport and Media:

The relationship between sport and the media is not a function of public service, nor does sport provide the media with access merely to increase public awareness. Rather, the sport media nexus is driven by commercial forces. The evolution of the sport media nexus, its strength, and the global power and influence of both of its component industries, has largely been driven by money. The media coverage of sport has become the central means by which sport organizations obtain revenue, while sport has become one of the most valuable 'properties' for media organizations. (Nichson,2007)

\section{UEFA Criteria and Management:}

UEFA has published UEFA criteria in order to protect football's sustainability and viability in a long term. With the introduction of such philosophy mean that:

- Enhancing the financial and economic capacities of the clubs,

- Rising their transparency and reputation,

- Fostering the institutionalization,

- Improving the management structure,

- Proving to survive through the next season with control of the annual financial, structure of the clubs,

- Increasing the clubs' competitive power of the national and international,

- Protecting the clubs' receivables.

Thus, it is expressed that can be obtained continuity and success in management with strengthening the economic and financial structure of the clubs, raising their transparency and reliability, and protecting their outstanding receivables.

It is needed to improve the quality standards with the main factors that compose the football game and that can be fulfilled under the name of club licensing system by means of a control mechanism.

Sports clubs operate in sports industry as a business that should be managed in the light of UEFA criteria in accordance with business general principles.

UEFA criteria are generally designed to gather some elements, Labor-money-time-material-land, together belonging to a business and that elaborated to provide its continuity.

The most important point for club's management 
is to struggle to manage the club's resources (labor, money, time etc.) more effectively.

Business Management even in a non-profit organization should be in the implementation effort for planning-organizing-leading-coordinating and controlling activities. Management function, management-finance-marketing and production cannot be sufficient for this reason additionally $H R$, Accounting-Public Relation-Management Style and have a system, input-process-output-feedback must be considered as a support functions.

The clubs, participated in UEFA leagues in the last 5 years were managed business principles and strategic management model because the between Club management and UEFA criteria should have a good correlation in the base of system.

In general, as being an industrial part, the football clubs for their survival that need more well-educated players, supporters, financial resources, sportive facilities, and proper management structure and organizational chart.

It is needed to bring those elements similar to production factors together like in a business in a planned and systematic way that labor (skilled player), capital (economic resource), land (sports facilities), and enterprise (club management). Because of UEFA criteria, sporting criteria refers labor, infrastructure refers land, financial criteria refer capital, Personnel and administrative criteria refer enterprise and legal criteria refers legal border of all works and sporting organization should be based on legal. So If you obey UEFA criteria exactly, you can find the good road map to success and be sustainability in your organizations.

\section{Results}

The implementation of UEFA criteria with licensing system give the sports Clubs weight to professionalism, financial stability, and reliability in effort to provide efficiency in management.

There is a positive relationship between UEFA criteria objective and functions and in Sports Club' Management.

There is a positive relationship between an Integration of UEFA Criteria in Sports Clubs and their success in the UEFA European League.

\section{Acknowledments}

With these study UEFA criteria give information about managing a sports organization but they do not give any suggestions on how and which management styles can be used. The responsibility of management styles are given to clubs.

This study has revealed that only applying the UEFA criteria was not enough for the stability of the organization for a long time and its sports success, so those criteria need to be supported with the business principles.

For an effective club management to attain and sustain a sporting achievement, it is needed to apply completely UEFA criteria, to divide the football clubs into two main functions in terms of administrative and technic, and to identify the job descriptions of those functions, and to provide a balance of power.

Depending on license criteria that is published by UEFA, it has used a road map for football clubs, regarding of corporate structure of UEFA to work, that identified the general rules like in a company structure and management that should be all the necessary factors of production in a systematic and effective way in order to transform football clubs to a corporate organization and make them sustainable.

Applications of UEFA criteria in the way of adjusting to their own organization implied by club authorities and written textbooks of those applications will contribute to the efforts of institutionalization.

Providing professional people who are experts in executive management will also create positive contributions during the period of adaptation of UEFA criteria and stability of those criteria.

Planning/Organizing/directing and controlling which are important actions in club management as well as in business management should be highly emphasized. However, not only finance/marketing/ Human Resources/Human Relations but also crises and problem solving/risk management/total quality management and relations with fans which take place in the functions of managing the business should be taken into consideration.

The club management as administration and football management should be seen as a field requiring 
expertise and the executive management department should include professionals who are trained as specialists and experienced in their own field.

\section{References}

A. Gupta, (2005) "Leadership in a Fast-Paced World: An Interview with Ken Blanchard," Mid-American Journal of Business 20: 7-11p.

Bernard J. Mullin \& Stephen Hardy \& William A. Sutton, (2007) Sport

Marketing, ISSN: 147-149-322-323p.

James Trecker, (2004) “The Freddy Factor”, SSSBJ, 10-16 May, 10;

J.J.P. Jansen, F. A. J. Van Den Bosh, and H. W. Volberda, (2006) "Managing Potential and Realized Absorptive Capacity: how do organizational antecedents matter?”, Academy of Management Journal 49, 999-1015p.

J.D. MacMillen, (2007) "Sport Law: A Managerial Approach", Journal of Sport Management, 21: 137-138p.

K. A. Karl, (2006) "Book and Resource Review," Academy of Management Learning

\&Education 5, 245-252p.

M.K. Takagawa, (1995), "Turn traditional work spaces into virtual offices”, Human Resources Professional: $11-14 \mathrm{p}$.
M. Littman, (1997), "Sponsors Take to the Court with the New Women's NBA", Marketing News 31 (5), 1-6p.

M. Nicholson, 2007, "Sport and Media", Managing the Nexus: 84

R. Katz, (1974), "Skills of Effective Administrator, Harvard Business Review", 90-102p.

R. N. Lussier \& D.C. Kimball, (2008), "Applied Sport Management Skills", 4-15p.

R.A. Baron, (2006) "Opportunity Recognition as Pattern Recognition", Academy of Management Perspective, 20, 104-111p.

S. Warfield, (2004) "Adu Mania Spurs MLS Attendance", SSSBJ, 8-14 November, 1, 38-39

H. Steinmann and G. Schreyögg, (1997), "Corporate Ethics and Management Theory", 4th ed., 132

S.H. Appelbaum, E. Adeland, and J. Harris, (2005), "Management of Sports Facilities: Stress and Terrorism since 9/11", Management Research News. 28 (7) 69-83p. Uluslararası Spor Araştırmaları Dergisi, (2010)

\section{Contact information}

SAMUR, Serdar, PhD (Corresponding author)

Address: $39-7265^{\text {th }}$ Street, Woodside, New York-USA

Phone: 9294719527

E-mail: ssamur_2002@yahoo.com 